\title{
2,5-Dialkyltetrahydrofurans, Common Components of the Cuticular Lipids of Lepidoptera
}

\author{
Stefan Schulz ${ }^{\mathrm{a}}$, George Beccaloni ${ }^{\mathrm{b}}$, Ritsuo Nishidac ${ }^{\mathrm{c}}$, Yves Roisin ${ }^{\mathrm{d}}$, \\ R. I. Vane-Wright ${ }^{\mathrm{b}}$, Jeremy N. McNeil ${ }^{\mathrm{e}}$ \\ a Institut für Organische Chemie, Universität Hamburg, Martin-Luther-King-Platz 6, \\ D-20146 Hamburg, Germany \\ b Department of Entomology, British Museum (Natural History), Cromwell Road, \\ London SW7 5BD, United Kingdom \\ c Pesticide Research Institute, Kyoto University, Kyoto, 606-01, Japan \\ d Faculté des Sciences C. P. 160, Université Libre de Bruxelles, Avenue F. D. Roosevelt 50, \\ B-1050 Bruxelles, Belgium \\ e Departément de biologie, Université Laval, Quebec, P. Q., G1K 7P4, Canada \\ Z. Naturforsch. 53c, 107-116 (1998); received October 22/November 17, 1997 \\ Lipids, Tetrahydrofurans, Cyclic Ethers, Lepidoptera, Cuticula \\ In more than 50 lepidopteran species 2,5-dialkyltetrahydrofurans were identified as com- \\ ponents of the cuticular lipids. The chain length of these compounds varies between $\mathrm{C}_{25}$ and \\ $\mathrm{C}_{37}$ and both cis- and trans-compounds are present. In addition, previously unknown 2-alkyl- \\ 5-(1-hydroxyalkyl)tetrahydrofurans were found in some species. The identification procedure \\ and synthesis of representative compounds are reported.
}

\section{Introduction}

The cuticle of insects is covered with a lipid layer the primary function of which is to prevent desiccation. Cuticular lipids can consist of hydrocarbons (the major group of compounds in most species), alcohols, aldehydes, ketones, wax esters, and fatty acids. In addition, dialkyl ethers, glyceride ethers or triglycerides have been found (Nelson and Blomquist, 1995).

Recently it has been shown that the parasitoid Apanteles kariyai locates its host, the common armyworm Pseudaletia separata, by detection of 2,5dialkyltetrahydrofurans present on the surface of the larvae (Takabayashi and Takahashi, 1986a,b). During our studies on pheromones of danaine butterflies we identified similar compounds associated with the male hairpencils (Schulz et al., 1993; Schulz and Nishida, 1996). In this study we show that 2,5-dialkyltetrahydrofurans occur as constituents of cuticular lipids of various genera of adult

Reprint requests to S. Schulz.

Institut für Organische Chemie, Technische Universität Braunschweig, Hagenring 30, 38106 Braunschweig, Germany.

Fax: +495313915272 .
Lepidoptera and discuss their identification and the synthesis of new derivatives.

\section{Material and Methods}

Samples, analysis and sample preparation

We studied the cuticular lipids of adult male butterflies of over 50 species, collected from different sources worldwide (Table I). For comparison we also examined males from a limited number of moth species (Table II). Finally, as tetrahydrofurans (THFs) present in cuticle of young Pseudaletia separata larvae serve as a kairomone for parasitic Hymenoptera (Takabayashi and Takahashi, 1986a, b), we compared the cuticular profiles of early and late instar larvae, as well as adult males of the true armyworm, P. unipuncta. Whole insects or body parts (see Tables I and II) were extracted with pentane or dichloromethane and stored at $-40^{\circ} \mathrm{C}$ until analysed by gas chromatography - mass spectrometry (GC-MS). Mass spectra $(70 \mathrm{eV})$ were obtained with a VG 70/250 S mass spectrometer coupled to a HewlettPackard HP 5890 A gas chromatograph and a Fisons MD-800 mass spectrometer coupled to a Fisons GC 8000. Gas chromatographic analyses were carried out with a Carlo-Erba Fractovap 2101 gas chromatograph equipped with a flame 
ionization detector and on-column or split/splitlessinjection. Separations were performed on capillary columns with apolar phases like $\mathrm{Rt}_{\mathrm{x}}-5$, DB-5, CPSil-8, or BPX-5. The last mentioned phase was used for the determination of retention indices. ${ }^{1} \mathrm{H}$ $\mathrm{NMR}$ and ${ }^{13} \mathrm{C}$ NMR spectra were obtained with Bruker WM 400 or AC250P instruments. Silylations were performed by adding $50 \mu \mathrm{l}$ MSTFA ( $N$-methyl- $N$-(trimethylsilyl)-trifluoroacetamide) to $50 \mu \mathrm{l}$ of a lipidic extract. After 30 minutes at $60{ }^{\circ} \mathrm{C}$, the silylated samples were concentrated under a stream of nitrogen and then analyzed.

\section{Synthesis of representative compounds}

For confirmation of our identifications, several THFs were synthesized (see Fig. 1). Furan was consecutively alkylated twice according to the method of Brandsma and Verkruijsse (1986). The 2,5-dialkylfuran obtained was then hydrogenated over palladium/charcoal, to yield a 99:1 mixture of cis- and trans-2,5-dialkyltetrahydrofurans. The alcohol 2-heptyl-5-(1-hydroxyoctadecyl)-tetrahydrofuran (C7/1HOC18-THF) was synthesized starting from 2-heptylfuran. After lithiation of the furan, octadecanal was added. The resulting 2heptyl-5-(1-hydroxyoctadecyl)-furan can be hydrogenated with rhodium on charcoal to yield a 1:1 mixture of the two diastereomers of cis-C7/ 1HOC18-THFs, which elute as one peak on an apolar gas chromatographic phase. Attempts to separate the enantiomers on different chiral cyclodextrine phases were unsuccessful. The synthetic compounds exhibited identical mass spectra and retention times to the natural compounds.

\section{2-Heptyl-5-octadecylfuran}

2-Heptylfuran was prepared according to the method of Brandsma and Verkruijsse (1986), by alkylation of furan with heptyl bromide. A second alkylation with octadedyl bromide yielded 2-heptyl-5-octadecylfuran.

${ }^{1} \mathrm{H}$ NMR $\left(250 \mathrm{MHz}, \mathrm{CDCl}_{3}\right): \delta=0.95(\mathrm{t}, 6 \mathrm{H}$, $\mathrm{CH}_{3}$ ), 1.24-1.40 (m, 38H, $\left.\mathrm{CH}_{2}\right), 1.63$ (quin, $4 \mathrm{H}$, $\left.\mathrm{H}-2^{\prime}\right), 2.60$ (t, 4H, H-1', $\left.J=7.8 \mathrm{~Hz}\right), 5.92(\mathrm{~s}, 2 \mathrm{H}$, $\mathrm{H}-3, \mathrm{H}-4)$.

EI-MS $(70 \mathrm{eV}): m / z(\%)=43(72), 57(39), 81$ (24), 95 (85), 107 (32), 127 (8), 179 (100), 193 (22), 291 (3), 323 (35), 337 (12), $418\left(83, \mathrm{M}^{+}\right)$.

\section{2-Heptyl-5-octadecyltetrahydrofuran}

A solution of 2-heptyl-5-octadecylfuran $(50 \mathrm{mg})$ in $5 \mathrm{ml}$ hexane was hydrogenated at 0.5 bar with $10 \% \mathrm{Pd} / \mathrm{C}$ as catalyst. After filtration, a 99:1 cis/ trans mixture of pure 2-heptyl-5-octadecyltetrahydrofuran was obtained.

${ }^{1} \mathrm{H}$ NMR $\left(250 \mathrm{MHz}, \mathrm{CDCl}_{3}\right): \delta=0.88(\mathrm{t}, 6 \mathrm{H}$, $\mathrm{CH}_{3}$ ), $1.20-1.45\left(\mathrm{~m}, 42 \mathrm{H}, \mathrm{CH}_{2}\right), 1.60$ (quin, $4 \mathrm{H}$, H-1'), 1.90 (m, 2H, H-3, H-4), 3.65-3.90 (m, 2H, $\mathrm{H}-2, \mathrm{H}-5)$.

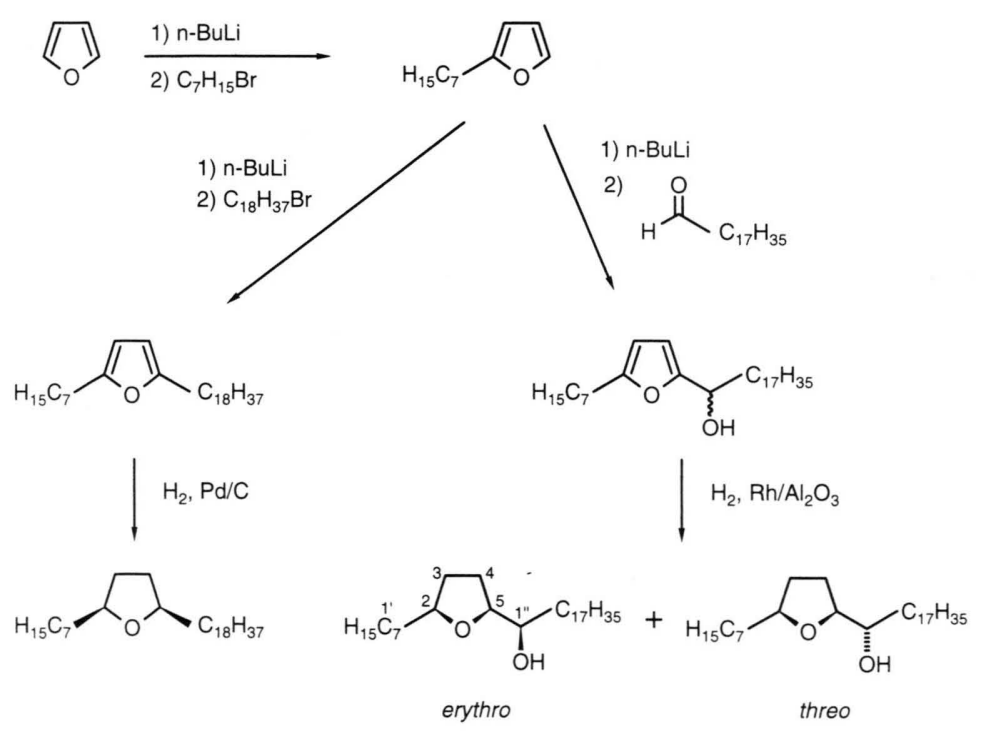

Fig. 1. Synthesis of $7 / 18-\mathrm{THF}$ and $7 /$ 1HO18-THF. 
${ }^{13} \mathrm{C}$ NMR $\left(62.9 \mathrm{MHz}, \mathrm{C}_{6} \mathrm{D}_{6}\right): \delta=14.4\left(\mathrm{C}-7^{\prime}\right.$, C18"), 23.1 (C-6', C-17"), 26.9 (C-2'), 29.8-30.3, 31.6 (C-3), $32.3\left({\left.\mathrm{C}-5^{\prime}\right)}^{\prime}, 32.4\right.$ (C-16'), 36.8 (C-1), 79.4 (C-2, C-5).

\section{2-Heptyl-5-(1-hydroxyoctadecyl)-furan}

A $1.6 \mathrm{~m}$ solution of $n$-butyllithium in hexane (1.5 $\mathrm{ml})$ was added to a stirred solution of 2-heptylfuran $(390 \mathrm{mg}, 2 \mathrm{mmol})$ in $4 \mathrm{ml} \mathrm{THF}$ at $0{ }^{\circ} \mathrm{C}$. After $2 \mathrm{~h}$, a solution of octadecanal $(500 \mathrm{mg}, 1.87 \mathrm{mmol})$ in $4 \mathrm{ml} \mathrm{THF}$ was added dropwise and the resulting mixture stirred for $3 \mathrm{~h}$ at room temperature. A saturated $\mathrm{NH}_{4} \mathrm{Cl}$ solution was added, and the mixture extracted three times with diethyl ether. The combined organic extracts were dried with $\mathrm{MgSO}_{4}$ and the solvent removed. The crude extract was purified by chromatography on $100 \mathrm{~g}$ neutral $\mathrm{Al}_{2} \mathrm{O}_{3}$ (Woelm, activity 3-4), giving $430 \mathrm{mg}$ of pure 2heptyl-5-(1-hydroxyoctadecyl)-furan (62\% yield).

${ }^{1} \mathrm{H}$ NMR $\left(\mathrm{CDCl}_{3}, 400 \mathrm{MHz}\right): \delta=0.88(\mathrm{t}, 6 \mathrm{H}$, $\left.J=6.8 \mathrm{~Hz}, \mathrm{CH}_{3}\right), 1.21-1.46\left(\mathrm{~m}, 38 \mathrm{H}, \mathrm{CH}_{2}\right), 1.62$ (quin, $2 \mathrm{H}, J=7.4 \mathrm{~Hz}, \mathrm{CH}_{2}-\mathrm{CH}_{2}$-furyl), 1.83 (m, $\left.2 \mathrm{H}, \mathrm{CH}_{2}-\mathrm{CHOH}\right), 2.59\left(\mathrm{t}, 2 \mathrm{H}, J=7.2 \mathrm{~Hz}, \mathrm{CH}_{2^{-}}\right.$ furyl), $4.60(\mathrm{t}, 1 \mathrm{H}, J=6.6 \mathrm{~Hz}, \mathrm{CH}-\mathrm{OH}), 5.89(\mathrm{~d}$, $1 \mathrm{H}, J=3.0 \mathrm{~Hz}, \mathrm{CH}), 6.10(\mathrm{~d}, 1 \mathrm{H}, J=3.0 \mathrm{~Hz}, \mathrm{CH})$.

\section{2-Heptyl-5-(1-hydroxyoctadecyl)-tetrahydrofuran}

A solution of $50 \mathrm{mg}$ 2-heptyl-5-(1-hydroxyoctadecyl)-furan in $3 \mathrm{ml}$ of a 3:1 methanol/diethyl ether mixture was stirred together with $10 \mathrm{mg}$ of a $5 \%$ $\mathrm{Rh} / \mathrm{Al}_{2} \mathrm{O}_{3}$ catalyst for $3 \mathrm{~h}$ under an atmosphere of hydrogen of 0.2 bar. The mixture was filtered and the solvent removed to give almost pure 2-heptyl5-(1-hydroxyoctadecyl)-tetrahydrofuran. Small amounts of 2-heptyl-5-octadecyltetrahydrofuran, formed by hydrogenolysis of the hydroxy group, were removed by chromatography on $\mathrm{Al}_{2} \mathrm{O}_{3}$. The analysis of NMR spectra according to Fujimoto et al. (1994) showed that a 1:1 mixture of the threoand erythro-cis-hydroxyalkyltetrahydrofurans was formed.

${ }^{1} \mathrm{H}$ NMR $\left(\mathrm{CDCl}_{3}, 400 \mathrm{MHz}\right): \delta=0.88(\mathrm{t}, 6 \mathrm{H}$, $\left.J=6.8 \mathrm{~Hz}, \mathrm{CH}_{3}\right), 1.20-2.00\left(\mathrm{~m}, \mathrm{CH}_{2}\right), 3.36(\mathrm{q}, 1 \mathrm{H}$, $J=6.1 \mathrm{~Hz}$, threo-CH-OH), $3.70(\mathrm{q}, 1 \mathrm{H}, J=6.6$ $\mathrm{Hz}$, threo-CH-O-C), 3.77-3.89 (m, 4H, threo- and erythro-CH-O-C, erythro- $\mathrm{CH}-\mathrm{OH})$.

${ }^{13} \mathrm{C} \mathrm{NMR}\left(\mathrm{CDCl}_{3}, 100 \mathrm{MHz}\right): \delta=14.1\left(\mathrm{C}-7^{\prime}\right.$, C-18"), 22.6 (C-6', C-17"), 23.8 (erythro-C-4), 25.7 (threo-C-3"), 26.0 (erythro-C-3"), 26.2 (erythro-C- $\left.2^{\prime}\right), 27.8$ (threo-C-4), 29.2-29.7 $\left(\mathrm{CH}_{2}\right), 31.4$ (C-3), $31.8\left(\mathrm{C}-5^{\prime}\right), 31.9\left(\mathrm{C}-16^{\prime \prime}\right), 32.6$ (erythro-C-2"), 34.0 (threo-C-2"), 35.9 (erythro-C-1'), 36.0 (threo-C-1'), 71.6 (erythro-C-1"), 74.5 (threo-C-1"), 79.6 (erythro-C-2), 79.9 (threo-C-2), 82.0 (erythro-C-5), 82.2 (threo-C5).

\section{Results}

In the current study, cuticular lipids of adult butterflies belonging to the Danainae, Heliconiinae, Ithomiinae (all Nymphalidae) and Pieridae, as well as noctuid, arctiid, pyralid, tortricid, and plutellid moth species were investigated. Because our primary interest is the chemical communication systems of male Lepidoptera, we analyzed body parts associated with suspected pheromone emitting structures. In some cases other body parts or live stages as well as females of the ithomiine Methona confusa were investigated, additionally (see Tables I and II).

The lipids were extracted as described and the extracts submitted to GC-MS. Long chain unbranched 2,5-dialkyltetrahydrofurans and related alcohols were identified in addition to the usual alkanes and other compounds. They exhibited distinct mass spectra, permitting easy location of the ring in the chain (Brandt and Djerassi, 1968; Zinbo and Jensen, 1985; Takabayashi and Takahashi, 1986a). The mass spectrum of 2-nonyl-5-octadecyltetrahydrofuran $\left(9 / 18-\mathrm{THF}^{*}\right)$ is depicted in Fig. 2A. The $\alpha$-cleavage next to the ring gives rise to intense $\mathrm{C}_{n} \mathrm{H}_{2 n-1} \mathrm{O}$-ions (A) that indicates the length of each side chain. These fragments are accompanied by characteristic small $\mathrm{C}_{n} \mathrm{H}_{2 n-3}$-ions (B), formed by additional loss of water. The molecular weight can be determined by the small ions M-1 and M-18.

In some species hydroxylated tetrahydrofuran derivatives were identified, which showed mass spectra exhibiting only one intense ion $\mathrm{A}$. The spectrum of 2-(1-hydroxyoctadecyl)-5-nonyltetrahydrofuran (C9/1HOC18-THF) is shown in Fig. 2B. The highest visible ion is $m / z=448$, which arises by loss of water from the molecular ion. The

\footnotetext{
* The numbers indicate the lengths of the side chains. Thus, 2-octadecyl-5-tridecyltetrahydrofuran is abbreviated as 13/18-THF.
} 

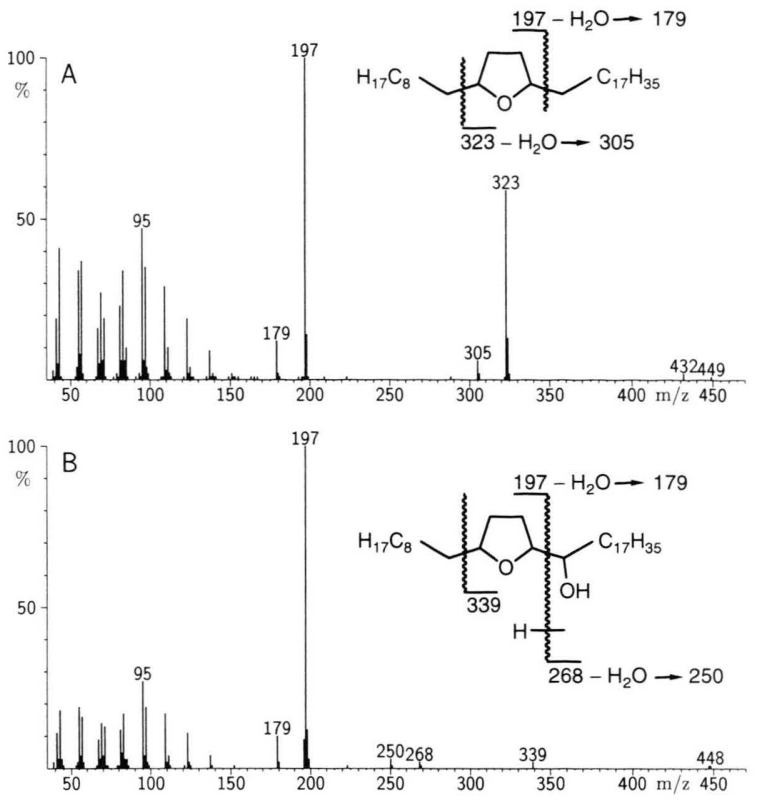

Fig. 2. Mass spectrum and fragmentation pattern of $\mathrm{A}$ : 2-octadecyl-5-nonyltetrahydrofuran (C9/C18-THF) B: 2-(1-hydroxyoctadecyl)-5-nonyltetrahydrofuran (C9/1HOC18-THF).

C-9 side chain can be deduced from the base peak at $m / z=197$. The second fragment A plus an additional oxygen was observed at $m / z=339$. The position of the oxygen atom is probably at C-1 of the octadecyl side chain, because $\alpha$-cleavage on the THF side plus hydrogen loss leads to $m / z=268$, which is accompanied by water elimination to furnish the ion $\mathrm{m} / z=250$. Silylation was performed to prove that the additional oxygen is part of a hydroxyl group. In the spectrum of silylated $\mathrm{C} 7 /$ 1HOC20-THF (Fig. 3) the base peak was found at $\mathrm{m} / \mathrm{z}=369$. This ion is formed by cleavage between the silyloxy group and the tetrahydrofuran ring.
The ions $\mathrm{A}$ are of low abundance and are found at $\mathrm{m} / z=169$ and $\mathrm{m} / z=439$. The identifications were verified by synthesis of reference compounds (see Materials and Methods).

Dialkyltetrahydrofurans with chain lengths between $\mathrm{C}_{25}$ and $\mathrm{C}_{37}$ were identified in cuticular lipids of 55 Lepidoptera species investigated (see Tables I and II). They occurred in mixtures containing both the cis- and trans-isomers, but these were not present in identical concentrations. On apolar phases, the cis-componds elute earlier than the respective trans-components. The retention indices of four synthetic compounds with a $\mathrm{C}_{29}$ carbon backbone were determined as follows: cis-11/ 14-THF 2963, trans-11/14-THF 2977, cis-9/16-THF 2967, trans-9/16-THF 2979, cis-7/18-THF 2974, trans-7/18-THF 2983, cis-5/20-THF 2984, and trans-5/20-THF 2991. The hydroxylated compound cis-7/1HO18-THF has a retention index of 3177.

Tetrahydrofurans with an odd number of carbons in the chain predominate in the natural waxes. The ring is always located in the middle of the chain and contains substituents which vary in length between $\mathrm{C}_{5}$ and $\mathrm{C}_{22}$. Positional isomers of the major components often show a difference of two carbons in the location of the ring. For example, the cuticular lipids of the ithomiine butterfly Ithomia salapia contain major amounts of 11/18THF and 13/16-THF as well as 13/18-THF and 15/ 16-THF. The major components usually contain a $\mathrm{C}_{16^{-}}, \mathrm{C}_{18^{-}}$, or $\mathrm{C}_{20}$ side chain and possess a total of 31,33 , or 35 carbon atoms. They are accompanied by tetrahydrofurans with an even number of carbons that do not show specific positional preferences. The natural mixtures can be quite complex. For example, more than 60 THF's were identified as constituents of the cuticular lipids of Amauris niavius after fractionation (Schulz et al., 1993).

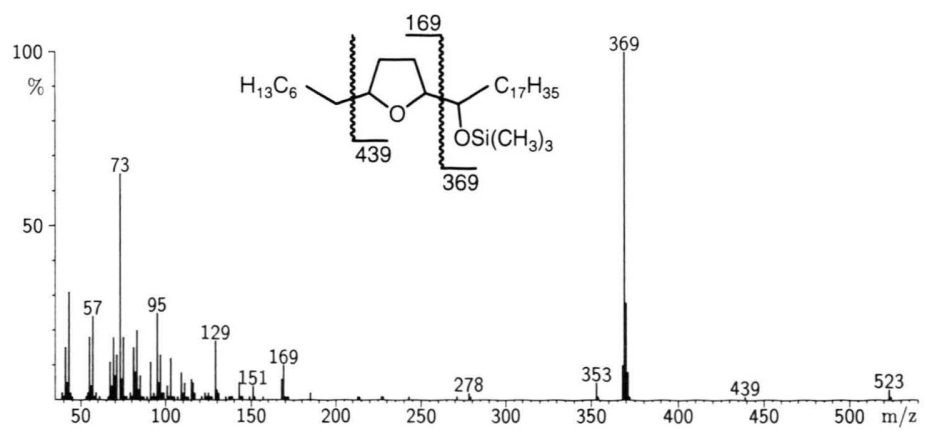

Fig. 3. Mass spectrum and fragmentation pattern of 2-heptyl-5-(1-trimethylsilyloxyoctadecyl)-tetrahydrofuran. 
Table I. Species, origin and major dialkyltetrahydrofurans present in the surface of butterflies. Body parts refers to the parts analyzed. WI: wings, WF: wings of female, CL: clasper; HP: hair pencils; BO: whole insect. A following + denotes inclusion of pheromone emitting structures in the sample, a - the opposite.

\begin{tabular}{|c|c|c|c|}
\hline Species & Origin & Body parts & Major tetrahydrofurans \\
\hline \multicolumn{4}{|l|}{ Pieridae } \\
\hline $\begin{array}{l}\text { Catopsilia pomona } \\
\text { Pieris rapae }\end{array}$ & $\begin{array}{l}\text { Sri Lanka } \\
\text { Germany }\end{array}$ & $\begin{array}{l}\mathrm{WI}+, \mathrm{WI}- \\
\mathrm{BO}+\end{array}$ & $\begin{array}{l}11 / 16 \\
\text { not detected }\end{array}$ \\
\hline \multicolumn{4}{|l|}{ Nymphalidae } \\
\hline \multicolumn{4}{|l|}{ Danainae } \\
\hline $\begin{array}{l}\text { Amauris albimaculata } \\
\text { Amauris damocles } \\
\text { Amauris echeria } \\
\text { Amauris hecate } \\
\text { Amauris niavius }{ }^{1} \\
\text { Amauris ochlea } \\
\text { Amauris tartarea } \\
\text { Danaus affinis } \\
\text { Danaus chrysippus } \\
\text { Danaus genutia } \\
\text { Danaus gilippus } \\
\text { Euploea core } \\
\text { Euploea klugii } \\
\text { Idea leuconoe } 2 \\
\text { Parantica aglea } \\
\text { Tirumala limniace }\end{array}$ & $\begin{array}{l}\text { Kenya } \\
\text { Togo } \\
\text { Kenya } \\
\text { Kenya } \\
\text { Kenya } \\
\text { Kenya } \\
\text { Kenya } \\
\text { Papua New Guinea } \\
\text { Kenya } \\
\text { Sri Lanka } \\
\text { USA } \\
\text { Sri Lanka } \\
\text { Sri Lanka } \\
\text { Japan } \\
\text { Sri Lanka } \\
\text { Sri Lanka }\end{array}$ & $\begin{array}{l}\mathrm{HP}+, \text { WI+ } \\
\mathrm{HP}+, \mathrm{WI}+ \\
\mathrm{HP}+, \text { WI+ } \\
\mathrm{HP}+ \\
\mathrm{HP}+, \text { WI+ } \\
\mathrm{HP}+, \text { WI+, WI- } \\
\mathrm{HP}+, \text { WI+ } \\
\mathrm{HP}+, \text { WI+ } \\
\mathrm{HP}+, \text { WI+ } \\
\mathrm{HP}+, \text { WI+, WI- } \\
\mathrm{HP}+, \text { WI+ } \\
\mathrm{HP}+ \\
\mathrm{HP}+ \\
\mathrm{HP}+, \text { WI- } \\
\mathrm{HP}+, \text { WI+, WI- } \\
\mathrm{HP}+, \text { WI+, WI- }\end{array}$ & $\begin{array}{l}7 / 18,9 / 18 \\
7 / 20,9 / 18 \\
7 / 20,9 / 18 \\
7 / 20,9 / 18,9 / 20 \\
7 / 20,9 / 18,9 / 20,11 / 18 \\
9 / 20 \\
9 / 18 \\
11 / 16 \\
11 / 16,11 / 18,13 / 16 \\
11 / 16 \\
11 / 16 \\
11 / 16 \\
11 / 16,13 / 14 \\
9 / 16,9 / 18 \\
7 / 18 \\
11 / 16\end{array}$ \\
\hline \multicolumn{4}{|l|}{ Ithomiinae } \\
\hline Callithomia hezia & Costa Rica & $\mathrm{WI}+$ & not detected \\
\hline Ceratinia tutia & Ecuador & WI+ & $11 / 18,13 / 16$ \\
\hline Dircenna dero & Argentina & $\mathrm{WI}+$ & $13 / 16,13 / 18$ \\
\hline Dircenna loreta & Ecuador & WI+ & $13 / 16$ \\
\hline Godyris zavaleta & Ecuador & WI+ & $11 / 18$ \\
\hline Heterosais edessa & Brazil & WI+ & not detected \\
\hline Heterosais nephele & Ecuador & $\mathrm{WI}+$ & $11 / 18,13 / 16$ \\
\hline Hypoleria orolina & Ecuador & WI+ & $9 / 20,11 / 18,13 / 16$ \\
\hline Hypomenitis andromica & Ecuador & WI+ & $11 / 18,13 / 16$ \\
\hline Hyposcada illinissa & Ecuador & $\mathrm{WI}+$ & $11 / 18,13 / 16$ \\
\hline Hypothyris anastasia & Brazil, Ecuador & $\mathrm{WI}+, \mathrm{WI}-$ & $9 / 20,11 / 20,13 / 18$ \\
\hline Hypothyris euclea & Ecuador & WI+ & $11 / 18,13 / 16,13 / 18,15 / 16$ \\
\hline Hypothyris mamercus & Ecuador & WI+ & $11 / 20,13 / 18,15 / 16$ \\
\hline Hypothyris moebiusi & Ecuador & $\mathrm{WI}+$ & $11 / 18,13 / 16,13 / 18,15 / 16$ \\
\hline Ithomia agnosia & Ecuador & WI+ & not detected \\
\hline Ithomia salapia & Ecuador & WI+ & $11 / 18,13 / 16,13 / 18,15 / 16$ \\
\hline Mechanitis polymnia & Brazil, Ecuador & WI+ & $13 / 18,15 / 16$ \\
\hline Mechanitis lysimnia & Brazil, Ecuador & WI+ & $13 / 18,15 / 16$ \\
\hline Melinaea ludovica & Brazil & $\mathrm{WI}+, \mathrm{WI}-$ & $7 / 20,9 / 20$ \\
\hline Melinaea menophilus & Brazil & $\mathrm{WI}+, \mathrm{WI}-$ & $11 / 18,13 / 16$ \\
\hline Methona confusa & Ecuador, Brazil & $\mathrm{WI}+, \mathrm{WI}-, \mathrm{WF}+$ & $9 / 16,9 / 18,9 / 20,11 / 18$ \\
\hline Napeogenes sylphis & Ecuador & WI+ & $11 / 16,13 / 18$ \\
\hline Oleria gunilla & Ecuador & WI+ & $13 / 18,15 / 16$ \\
\hline Oleria padilla & Ecuador & WI+ & $9 / 18,11 / 16,11 / 18,13 / 16$ \\
\hline Pseudoscada timna & Ecuador & WI+ & $11 / 16,11 / 18,13 / 18$ \\
\hline Pteronymia vestilla & Brazil & $\mathrm{WI}+$ & $11 / 18,13 / 16$ \\
\hline Prittwitzia hymenaea & Argentina & WI+ & $11 / 18,13 / 16$ \\
\hline Scada kusa & Ecuador & WI+ & $9 / 18,11 / 16,11 / 18,13 / 16$ \\
\hline Thyridia psidii & Brazil & $\mathrm{WI}+, \mathrm{WI}-$ & $7 / 20,9 / 18,9 / 20$ \\
\hline Tithorea harmonia & Brazil, Ecuador & WI+ & $9 / 18,11 / 16,11 / 18,13 / 16$ \\
\hline Tithorea tarricina & Costa Rica & WI+ & $11 / 16$ \\
\hline
\end{tabular}


Table I. Continued.

\begin{tabular}{llll}
\hline Species & Origin & Body parts & Major tetrahydrofurans \\
\hline Heliconiinae & & & \\
\hline $\begin{array}{l}\text { Argynnis paphia } \\
\text { Dryas iulia }\end{array}$ & Germany & CL+, WI+, WI - & $11 / 18$ \\
Heliconius charitonia & Costa Rica & CL+, WI+ & not detected \\
Heliconius cydno & Costa Rica & CL+ & $9 / 18,11 / 16$ \\
Heliconius doris & Costa Rica & CL+ & $11 / 18,9 / 20,11 / 20,13 / 18$ \\
Heliconius erato & Costa Rica & CL+, WI+ & $9 / 18,11 / 16,11 / 18,13 / 16$ \\
Heliconius hecale & Costa Rica & CL+, WI+ & not detected \\
Heliconius hewitsoni & Costa Rica & CL+, WI+ & $9 / 16,9 / 18,11 / 16$ \\
Heliconius ismenius & Costa Rica & CL+, WI+ & not detected \\
Heliconius melpomene & Costa Rica & CL+, WI+ & $7 / 20$ \\
Heliconius telesiphe & Costa Rica & CL+, WI+ & not detected \\
\hline
\end{tabular}

1 Schulz et al. (1993).

2 Schulz and Nishida (1996).

Table II. Species, origin and major dialkyltetrahydrofurans present in the surface lipids of adult moths. Body parts refers to the parts analyzed. LE: legs; CL: clasper; BO: whole insect. A following + denotes inclusion of pheromone emitting structures in the sample, a - the opposite.

\begin{tabular}{|c|c|c|c|}
\hline Species & Origin & Body parts & Major tetrahydrofurans \\
\hline \multicolumn{4}{|l|}{ Arctiidae } \\
\hline $\begin{array}{l}\text { Creatonotos transiens } \\
\text { Panaxia quadripunctaria }\end{array}$ & $\begin{array}{l}\text { Indonesia } \\
\text { Germany }\end{array}$ & $\begin{array}{l}\mathrm{BO}- \\
\mathrm{BO}-\end{array}$ & $\begin{array}{l}\text { not detected } \\
\text { not detected }\end{array}$ \\
\hline \multicolumn{4}{|l|}{ Noctuidae } \\
\hline $\begin{array}{l}\text { Actebia fennica } \\
\text { Autographa gamma } \\
\text { Mamestra configurata } \\
\text { Pseudaletia (or Mythimna) unipuncta } \\
\text { Spodoptera frugiperda }\end{array}$ & $\begin{array}{l}\text { Canada } \\
\text { Germany } \\
\text { Canada } \\
\text { Canada } \\
\text { USA }\end{array}$ & $\begin{array}{l}\mathrm{BO}+ \\
\mathrm{BO}+ \\
\mathrm{BO}+ \\
\mathrm{BO}+ \\
\mathrm{LE}+, \mathrm{CL}+\end{array}$ & $\begin{array}{l}\text { not detected } \\
\text { not detected } \\
11 / 16 \\
\text { not detected } \\
13 / 16\end{array}$ \\
\hline \multicolumn{4}{|l|}{ Plutellidae } \\
\hline \multicolumn{4}{|l|}{ Pyralidae } \\
\hline $\begin{array}{l}\text { Homeosoma electellum } \\
\text { Ostrinia nubilalis }\end{array}$ & $\begin{array}{l}\text { Canada } \\
\text { Canada }\end{array}$ & $\begin{array}{l}\mathrm{BO}+ \\
\mathrm{BO}+\end{array}$ & $\begin{array}{l}\text { not detected } \\
\text { not detected }\end{array}$ \\
\hline \multicolumn{4}{|l|}{ Tortricidae } \\
\hline $\begin{array}{l}\text { Choristoneura fumiferana } \\
\text { Choristoneura rosaceana }\end{array}$ & $\begin{array}{l}\text { Canada } \\
\text { Canada }\end{array}$ & $\begin{array}{l}\mathrm{BO}+ \\
\mathrm{BO}+\end{array}$ & $\begin{array}{l}\text { not detected } \\
\text { not detected }\end{array}$ \\
\hline
\end{tabular}

1 Larvae of the 3 rd instar contained $11 / 20$ and $13 / 18$ as major THFs, while 6 th instar larvae did not contain any THFs.

The hydroxylated tetrahydrofurans always contain the hydroxy group at $\mathrm{C}-1$ of the longer side chain. These alcohols, normally present only in small amounts, were identified by us in six ithomiine species: Ceratinia tutia, Heterosais nephele, $\mathrm{Hy}$ pomenitis andromica, Mechanitis lysimnia, M. po- lymnia, and Scada kusa. In the last named species they make up the largest part of the THFs found in the cuticular lipids. As with the parent THFs, two peaks with similar mass spectra could be observed by separation on apolar gas chromatographic phases. They represent the cis- and trans- 
compounds, because the erythro- and threo ciscompounds formed during our synthesis could not be separated by GC. Thus, which of the four possible diastereomers occur naturally is unknown.

The relative amount of THFs in the cuticular lipids varies from less than $5 \%$ in most species to more than $70 \%$ of total cuticular lipids in other species. As an example, the results of the analysis of the wing lipids of the ithomiine butterfly Melinaea ludovica are presented in Table III and Fig. 4. The THFs are the prominent lipids, especially $7 /$ 20 -THF and $9 / 20$-THF. They are accompanied by some hydrocarbons, aldehydes and steroids. Because small amounts of hydroxyl containing compounds did not show distinct peaks on our column,

Table III. Constituents of the cuticular lipids of wings from Melinaea ludovica (Ithomiinae). Numbers (No) refer to Fig. 4. Relative concentrations are given (conc): +++ major component, ++ minor component, + trace component.

\begin{tabular}{|c|c|c|}
\hline No & Compound & Conc \\
\hline 1 & heptacosane & + \\
\hline 2 & squalene & + \\
\hline 3 & nonacosane & + \\
\hline 4 & 7/18-THF & + \\
\hline 5 & triacontane & + \\
\hline 6 & 7/19-THF & + \\
\hline 7 & 6/20-THF & + \\
\hline 8 & hentriacontane & + \\
\hline 9 & cholesterol & ++ \\
\hline 10 & 9/18-THF & + \\
\hline 11 & 7/20-THF & +++ \\
\hline 12 & ergostenol & + \\
\hline 13 & triacontanal & + \\
\hline 14 & 9/19-THF & ++ \\
\hline 15 & $8 / 20-\mathrm{THF}$ & + \\
\hline 16 & 7/21-THF & + \\
\hline 17 & stigmasterol & + \\
\hline 18 & 11/18-THF & + \\
\hline 19 & 9/20-THF & +++ \\
\hline 20 & $10 / 20-\mathrm{THF}$ & + \\
\hline 21 & 9/21-THF & + \\
\hline 22 & 13,21-dimethylpentatriacontane & ++ \\
\hline 23 & docosanoic acid & + \\
\hline 24 & tetracosanoic acid & + \\
\hline 25 & hexacosanoic acid & + \\
\hline 26 & 8-nonacosanol & + \\
\hline 27 & 9-nonacosanol & + \\
\hline 28 & 10-nonacosanol & + \\
\hline 29 & cholestadienol & + \\
\hline 30 & 9-triacontanol & + \\
\hline 31 & 7/1HO19-THF & + \\
\hline 32 & 11-hentriacontanol & + \\
\hline 33 & 7/1HO20-THF & ++ \\
\hline 34 & 13-tritriacontanol & + \\
\hline 35 & 9/1HO20THF & + \\
\hline
\end{tabular}

silylated extracts were analyzed. Thus, several hydroxy-compounds could be identified, including long chain secondary alcohols and hydroxylated THFs.

There is a very marked difference in the presence of THFs in the cuticular lipids of those butterflies and moths examined. For example, of the 60 species of butterflies investigated $87 \%$ had THFs while they were only found in $17 \%$ (two) of the 12 moth species examined. It should be noted that in the case of the butterflies, the choice of species and of the body parts examined was not systematic but rather associated with our interest in male sex pheromones. Thus the reported absence of THFs in certain species must be viewed with some caution. However, the moths were analysed specifically for the presence of THFs. Thus, in the species reported here to lack THFs, these lipids are truly absent from the cuticle rather than undetected due to a bias in sampling. It is clear that the relative frequency and role of THFs in different parts of the cuticles of adult butterflies and moths needs to be examined further.

Our studies show that THF levels in different development stages of a given species may also change during the insect's life cycle. While THFs are present in 3rd instar larvae (major components are 11/18-THF and 13/16-THF) of P. unipuncta, they were absent in both 6th instar larvae and adult males. This suggests that THFs may play a specific role at certain times in the insect's development.

\section{Discussion}

The results of our analysis show that the cuticular lipids of many Lepidoptera contain 2,5-dialkyltetrahydrofurans. In all cases in which different body parts were investigated, similar THF patterns were found. They are not restricted to a distinct body part. The species investigated were selected because of our interest in male butterfly pheromones, and not for complete coverage of the Lepidoptera. Therefore the conclusion that the THFs occur preferentially in Nymphalidae subfamilies should not be drawn, because the species selection is biased towards that family. Moreover, skipper butterflies (Hesperioidea) and moth groups now thought to be more closely related to the butterflies (e. g. Hedylidae, Uraniidae, Geo- 


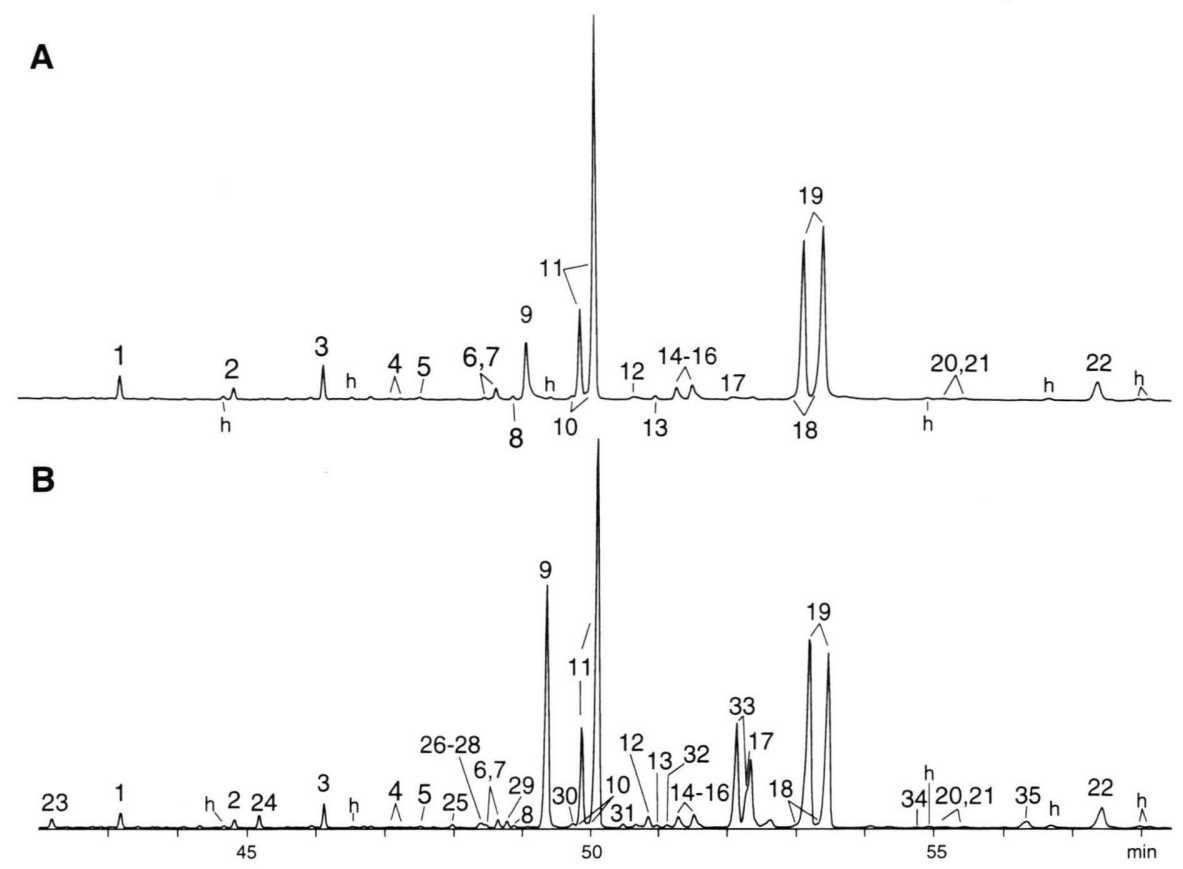

Fig. 4. Gas chromatogram of the wing cuticular lipids of Melinaea ludovica. Numbers refer to Table III. A: extract of cuticular lipids; B: extract after silylation; numbers of compounds containing hydroxyl groups refer to the respective silylated products. h: hydrocarbon.

metridae: de Jong et al. (1996)) have not been sampled. Instead, we propose that the THFs constitute important components of cuticular lipids present in many Lepidoptera and other insect orders. They have also been identified in the locust Schistocerca gregaria (W. Francke, personal communication). Nevertheless, they seem to be more abundant in butterflies than in moths because we encountered moth species lacking them more often than such butterfly species.

Their distinctive mass spectra should ease the identification of further species containing THF. The simple 2,5-dialkyltetrahydrofurans described have not been reported from any natural source other than Lepidoptera before. They represent simple models of the acetogenic tetrahydrofurans identified from the plant family Annonaceae, which exhibit numerous pharmacological effects (Cavé et al., 1996). Other ethers have only rarely been identified in insects so far (Nelson and Blomquist, 1995).

The biosynthesis of THFs is unknown. Interestingly, the major THFs of Melinaea ludovica are 7/ 20-THF and 9/20-THF. Minor components of the wing lipids were identified as 11-hentriacontanol and 13-tritriacontanol (see Table III). It is well known that secondary alcohols can cyclize preferentially to THFs under radical-forming conditions, giving a mixture of the respective cis- and transcompounds (Mihailovic et al., 1973). By radical cyclization of for example 11-hentriacontanol to the shorter side of the carbon chain, as depicted in Fig. 5, a mixture of cis- and trans-7/20-THF is obtained. This cyclization may be enzyme controlled, because the reaction takes place on one side only. Another possible biosynthetic precursor, the short-chain tetrahydrofurfuryl-ring-containing acid 5-(5-(1-hydroxyheptyl)-tetrahydrofurfur-2-yl)pentanoic acid, was identified from wool fat (Ito et al., 1971). Such tetrahydrofurfuryl acids (probably formed by oxidations of common unsaturated $\mathrm{C}_{16^{-}}$or $\mathrm{C}_{18}$ fatty acids) could be elongated by acetate units to the required chain length in a elongation-decarboxylation process similar to the biosynthesis of hydrocarbons (Nelson and Blomquist, 1995). Nevertheless, the varying chain length on both sides of the ring excludes one single acid as precursor. For the $\alpha$-hydroxylated tetrahydrofu- 


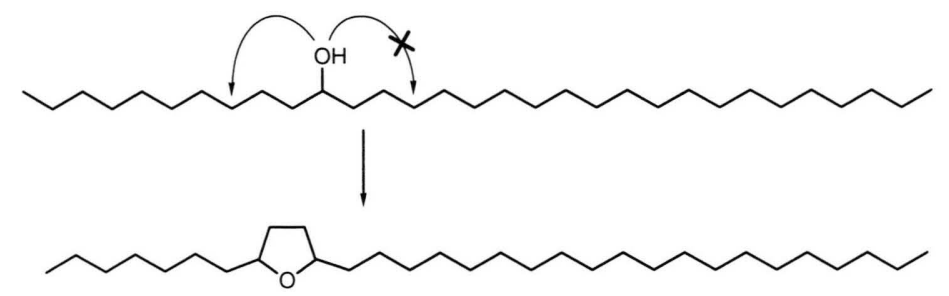

Fig. 5. Possible formation of 7/20-THF from 11-hentriacontanol by radical cyclization. rans from the Annonaceae a biosynthetic pathway starting from 1,4-dienes has been proposed (Cavé et al., 1996). After epoxidation of the double bonds, a ring opening-ring closure process can lead to such compounds. This model cannot explain the formation of the unfunctionalized THFs of the butterflies and it also does not explains their characteristic cis/trans-mixtures.

The primary function of the THF can be assumed to be to prevent desiccation of the insect, as has been established for other insect waxes (Nelson and Blomquist, 1995). However, it is well known that ethers can stabilize radicals at the $\alpha$ position and are thus prone to autooxidation. The long side chains may further stabilize such radicals. Whether this leads to antioxidative properties of the THFs or in contrast promotes oxidative degradation of the wax layer or the cuticle remains unclear. Thus, given the marked differences observed between the occurrence of THFs in diurnal and nocturnal Lepidoptera, as well as within the life cycle of a single species, it is evident that considerably more research is required to elucidate their biosynthesis and function in insects with different life histories. Furthermore, from a broader chemical ecology perspective, the intraspecific differences may provide a better understanding of hostparasitoid interactions. For example, the majority of hymenopterous parasitoids attacking $P$. unipuncta larvae preferentially oviposit in early instar individuals. Thus, the presence of THFs in $3 \mathrm{rd}$ but not 6th instar larvae may play an important role in host selection if, as reported for the P. separataA. kariyai system (Takabayashi and Takahashi, 1986a,b), these cuticular lipids serve as a kairomone for the parasitoids.

\section{Acknowledgments}

We are indebted to M. Boppré, K. S. Brown Jr., D. Schneider, and J. R. Trigo for the supply and identification of butterflies as well as to W. Francke for helpful comments on the manuscript. S. S. likes to thank the Deutsche Forschungsgemeinschaft (DFG) and the Fonds der chemischen Industrie for financial support.
Brandsma E. and Verkruijsse H. (1986), Preparative Polar Organometallic Chemistry, Vol. 1. Springer, Berlin, Heidelberg.

Brandt R. and Djerassi C. (1968), Massenspektren von $\alpha$-substituierten Tetrahydrofuranen. Helv. Chim. Acta 51, $1750-1762$.

Cavé A., Frigadère B., Laurens A. and Cortes D. (1996), Acetogenins from Annonaceae. In: Prog. Chem. Org. Nat. Prod. (Herz W., Kirby G. W., Moore R. E., Steglich W. and Tamm C., eds.), Springer, Heidelberg, vol. 70, pp. $81-288$.

Fujimoto Y., Murasaki C., Shimada H., Nishioka S., Kakinuma K., Singh S., Singh M., Gupta Y. K. and Sahai M. (1994), Annonaceous acetogenins from the seeds of Annona squamosa. Non-adjacent bis-tetrahydrofuranic acetogenins. Chem. Pharm. Bull. 42, 1175-1184.
Ito S., Endo K. and Inoue S. (1971), 10(S)-Hydroxy$6(S), 9(S)$-oxidohexadecanoic acid, a new acid in wool fat. Tetrahedron Lett., 4011-4014.

de Jong R., Vane-Wright R. I. and Ackery P. R. (1996), The higher classification of butterflies (Lepidoptera): problems and prospects. Entomologica Scandinavica 27, 65-101.

Mihailovic M. L., Gojkovic S. and Konstantinovic S. (1973), Stereochemistry of cyclic ether formation - II. Intramolecular cyclisation of secondary aliphatic alcohols to tetrahydrofurane-type ethers. Tetrahedron $\mathbf{2 9}$, 3675-3685.

Nelson D. R. and Blomquist R. J. (1995), Insect waxes. In: Waxes: Chemistry and Molecular Biology and Functions (Hamilton R. J., ed.). The Oily Press, Dundee, pp. $1-90$. 
Schulz S., Boppré M. and Vane-Wright R. I. (1993), Specific mixtures of secretions from male scent organs of African milkweed butterflies (Danainae). Phil. Trans. R. Soc. Lond. B 342, 161-181.

Schulz S. and Nishida R. (1996), The pheromone system of the male danaine butterfly Idea leuconoe. Bioorg. Med. Chem. 4, 341-349.

Takabayashi J. and Takahashi S. (1986a), Effect of kairomones in the host searching behavior of Apanteles kariyai Watanabe (Hymenoptera: Braconidae) and a parasitoid of the common armyworm Pseudaletia separata Walker (Lepidoptera: Noctuidae). II: Isolation and identification of arrestants produced by the host larvae. Appl. Ent. Zool. 21, 114-118.
Takabayashi J. and Takahashi S. (1986b), Effect of kairomones in the host searching behavior of Apanteles kariyai Watanabe (Hymenoptera: Braconidae) and a parasitoid of the common armyworm Pseudaletia separata Walker (Lepidoptera: Noctuidae). III: Synthesis and bioassay of arrestants and related compounds. Appl. Ent. Zool. 21, 519-524.

Zinbo M. and Jensen R. K. (1985), Identification and determination of 16-carbon 2,5-dialkyloxolanes in autoxidized n-hexadecane samples by capillary gas chromatography and mass spectrometry. Anal. Chem. 57, 315-319. 